\title{
4
}

\section{Turnbull versus Shorten: The Major Party Leadership Contest}

\author{
Paul Strangio and James Walter
}

\section{The dilemma of leadership in a time of leadership insecurity}

Federal election success has been a poor guarantee of leadership security in Australia's recent past. The 2016 campaign was the third in succession not to be fought by the leader who had emerged as Prime Minister from the previous election. Ironically, having capitalised mightily on the Labor leadership civil war between Kevin Rudd and Julia Gillard, Tony Abbott's fate mirrored Rudd's - a first-term prime minister overthrown by a party room insurrection (see Errington and van Onselen 2015). Yet Malcolm Turnbull's replacement of Abbott as Liberal leader and prime minister in September 2015 aroused nothing like the degree of community shock or resentment associated with Rudd's removal of June 2010. Putting to one side the uncomfortable question of whether this reflects greater forgiveness of ambition by male rather than female aspirants (Hall and Donaghue 2012), a reason Abbott's downfall failed to astonish was that there had been several months to prepare for the prospect. Abbott's hold on office had been tenuous since February 2015, when he unconvincingly staved off a leadership spill motion. And despite Abbott's attempt to incite public indignation when facing party room defeat ('our party is better than this ... our government is better than this and, by God ... 
our country is so much better than this' (2015)), there was not sufficient goodwill for him within the electorate for that appeal to gain traction. The consistently poor poll ratings that had plagued Abbott in office seemed to confirm that his hyperaggression as opposition leader, and a related stubborn public coolness towards him even when the Coalition prevailed at the 2013 election (Strangio and Walter 2015: 56), had helped booby trap his own prime ministership.

But was there another factor? Had Australians grown inured to the spectacle of prime ministerial assassination and, schooled by several years of leadership upheaval, developed better appreciation of the reality that the office is, after all, the gift of the party room? The 2007 federal election, which ushered in the recent era of prime ministerial instability, had been characterised by a new high-water mark of the personalisation of political campaigning in Australia. As encapsulated in Labor's successful 'Kevin '07' slogan, Rudd's personality and his carefully choreographed media profile dominated Labor's appeal to the electorate (Jackman 2008), which in turn licensed his domineering prime ministerial leadership. Yet Rudd's subsequent rollercoaster trajectory afforded a sobering lesson in the perils of excessively personalised leadership, and not only for a traumatised Labor Party.

Indeed, if there was a dominant theme to the contest between Turnbull and his Labor opponent, Bill Shorten, at the 2016 election, it is of leaders hedged by their own parties: of a contraction in autonomy between leaders and their parties. This is not to say that the respective campaigns of the Coalition and Labor were not chiefly centred upon Turnbull and Shorten respectively - they were. Nor is it to suggest that voters' estimate of the virtues of the each of the leaders (their competence, authenticity, trustworthiness and so on) was not a significant influence on the result of the election. Leadership matters. However, against the background of the leadership upheavals of the previous decade, neither Turnbull nor Shorten were prepared to create much distance between themselves and their parties. This created another dilemma. At a time when party bases are narrowing, or at the very least not keeping pace with a diversifying society, close identification with the party (or even more problematically an ideological strain within it) can limit leadership affinity with the electorate. The quandary was most acute for Turnbull, for the reason that he came to the prime ministership with the expectation that he possessed an appeal to the electorate that transcended his party, but he could only maintain internal support by observing limits that obviated that appeal. 


\section{Background to the campaign}

The September 2015 decision of the Liberal party room to oust Abbott and return Turnbull to the leadership - he had been opposition leader from September 2008 to December 2009-did seem to reaffirm the logic of personalisation with the calculation that the government's survival depended on Turnbull's superior public popularity. In making his case against Abbott's leadership, Turnbull emphasised that the Coalition had trailed in 30 consecutive Newspolls and required a more persuasive communicator-in-chief (Errington and van Onselen 2015: 198). Stylistically, the difference between the two leaders was stark. Whereas Abbott predominantly traded in fear and threat, Turnbull's emotional signature was optimism. 'There has never been a more exciting time to be alive than today and there has never been a more exciting time to be an Australian,' he proclaimed upon becoming Prime Minister (Turnbull 2015). But, as detailed later, it was soon apparent that Turnbull, long regarded as a philosophical outlier in his party because of his progressive inclinations, was not prepared to rock the boat on conservative policy positions established under Abbott, most emblematically in the areas of climate change and same-sex marriage. This invited scepticism about what was substantially different between his and his predecessor's government, a matter left unresolved by Turnbull's resort to the clumsy-and soon abandoned-slogan that he was offering, 'continuity and change' (Koziol 2016a). The price was an erosion of his authenticity in the eyes of voters, and a diminution of what undoubtedly had been an important element of his appeal compared to Abbott: that he was not perceived narrowly as a partisan warrior, and could reach out to a broader constituency.

Initially, that appeal had been abundantly evident with the public responding buoyantly to the removal of the deeply unpopular Abbott, and to the promise of Turnbull. The Coalition streaked ahead in the polls and Turnbull recorded dizzying leadership ratings. By November 2015, Newspoll found him boasting a net approval rating of 38 points-the highest for a prime minister since Rudd in 2009-and a mammoth 49 per cent lead as preferred prime minister over Shorten (Hudson 2015a). Coinciding with this, Labor's focus-group research showed Turnbull 'peeling off voters deemed to be "soft Labor"... energised by issues like same-sex marriage, climate change and a republic' (Bramston 2016a). During the early months of 2016, however, the gloss rapidly came off Turnbull as the (excessive) expectations of him went unfulfilled 
and the constraints he was operating under grew manifest. This was made worse by his dithering over tax policy. Though the Coalition was still strongly favoured to be returned to government when he officially called the election in May 2016 - a common journalistic construction was that it was Turnbull's 'to lose' (e.g. Kelly 2016a)—he entered the campaign with his approval rating sliding (Kenny 2016a; Medhora 2016) and escalating confusion about his prime ministerial identity. A popular street art poster of Turnbull mockingly titled 'Fizza' epitomised the rising tide of disappointment. But his promise had not completely dissipated: a decisive election victory, anticipated by many commentators, would deliver him the authority to assert his true colours within his government and party.

On the other side of the political fence, Shorten's journey to the 2016 election had been even more evidently one of closeness - and, in this case, natural affinity - between leader and party. Unlike Turnbull, Shorten was unmistakeably a creature of his party as a former national secretary of the Australian Workers' Union (AWU) and long-time factional player. He was the first Labor leader to survive a full term since Kim Beazley in 1998-2001. That longevity was aided by Shorten being elected under new rules, adopted by Caucus in 2013, meaning that for the first time a major Australian political party granted rank-and-file members a say in leadership selection. Under a hybrid system that evenly weights party room and ordinary member votes, Shorten narrowly won the leadership from Anthony Albanese despite securing only 40 per cent of the rank-andfile vote, but with two thirds of Caucus support. Nevertheless, by raising the threshold for triggering a leadership contest (a petition of 60 per cent of Caucus is required in opposition and 75 per cent in government), and removing the option for a quick strike against an incumbent, the new rules undoubtedly insulated Shorten's leadership during the Turnbull honeymoon period when otherwise all the usual omens were in place for a challenge. These included dismal public poll numbers, intriguing by right-wing factional heavyweights and the circulation with menace of internally commissioned focus-group research on Shorten's 'diabolical' standing with voters (Bramston 2016a, 2016b).

Shorten's survival, however, also owed something to Labor still being chastened by the leadership bloodletting of the Rudd-Gillard era and, more positively, his diligent efforts to heal those wounds and restore solidarity to the party's ranks. Campaigning for the leadership in 2013, Shorten had vowed that, if successful, 'you will hear less about I and more about we. The era of the messiah is over' (quoted in Strangio and 
Walter 2015: 60). If this was a pragmatic pitch to a party burnt by the imperious Rudd, a major profile of Shorten published at the beginning of the 2016 election campaign observed he had indeed delivered on that promise of collective leadership since 2013. '[I]n the past three years, Shorten has never styled himself as being somehow bigger than the party ... he has consistently prioritised unity over decisiveness' (Murphy 2016a). In another signal of his enmeshment with the party and wider labour movement, Shorten had also declined to distance himself from his trade union origins. In a personal memoir-cum-policy manifesto released in early 2016, he directly attributed his consensual leadership approach to practices he had perfected as an AWU official and declared that he still thought 'like an [union] organiser' (Shorten 2016: 33, 42, 45). Shorten's team orientation was further demonstrated by his facilitating lengthy internal conversations on policy, while the headline policies developed through those deliberations-significant public investment in health, education and infrastructure, and redistributive measures in superannuation, negative gearing and capital gains — reinforced the image of a leader in simpatico with Labor traditions.

Arguably, Shorten's modest leadership style and tribal allegiance, together with a lingering reputation as a party fixer (Marr 2015), inhibited the development of a connection with the electorate (Strangio 2016). His lack of resonance with the public loomed not so much as a liability during Abbott's prime ministership with Labor consistently ahead in the polls regardless, but came under intense scrutiny during the early romance of Turnbull's ascension. The internal focus-group reactions to the beleaguered Shorten in that period were cruel. He was variously described as 'bland', 'inadequate' and 'blah' (Bramston 2016b). Weathering the initial surge of support for Turnbull, however, he entered the election campaign still as underdog, but incrementally gaining ground on his rival.

\section{Turnbull's campaign}

Turnbull's personal style, and the character of his performance between September 2015 (when he overthrew Abbott) and the commencement of the 2016 election are important in contextualising his campaign. Victorian Liberal Party president Michael Kroger argued persuasively that the nature of the campaign must be understood in relation to the leadership behaviour and policy confusion that preceded it (see Choahan 2016). 
Notwithstanding past failures (as leader of the republican movement and in his first incarnation as Liberal Party leader), Turnbull's public record in business, journalism and the law encouraged the belief that he was a man of considerable capacity: courageous in the pursuit of his objectives, an independent thinker, intelligent, articulate, imaginative, driven by endless curiosity to hoover up information, and hence enormously well informed. He was also opinionated, did not suffer fools gladly, preferred his own view to that of any other and married boldness with aggression when confronted (Crabb 2016; Manning 2015). Yet, there was a hint that he needed direction to harness these capacities effectively (Crabb 2016). To whom, now, should he turn: was it the electorate opinion or the party to which he should respond? To depend upon the latter was to invite electoral problems. Typically, the leader is a powerful figure in the Liberal Party (Brett 2013), but in the fractious context in which Turnbull had defeated Abbott, he had made assurances to the party Right—a cohort whose preferences are demonstrably at variance with majority views on key issues (see further below).

This point would prove crucial. It had been argued before his second incarnation as party leader that:

Turnbull must do five things to mollify the Right: stick to the harsh border protection policies, not seek to adjust the climate change policy, preserve the party room's right to decide whether a vote on gay marriage becomes a matter of conscience, avoid the temptation to reinvigorate the republic debate and show he can work constructively with the Nationals (van Onselen 2015: 22).

These would be significant restraints, given that he had made a series of bold statements and speeches between 2009 and 2015, most of a small 'l' liberal bent, with many well outside his portfolio and at odds with then Coalition orthodoxy (Manne 2012). Indeed, the poll popularity that eventually saw him replace Abbott was thought to have stemmed from precisely this willingness to go 'off message' in relation to the muscular conservatism of the Abbott regime. On assuming the prime ministership, he spoke effusively about innovation, the cities and reinvigorating an 'adult' conversation with the electorate and trusting their intelligence rather than resorting to sloganeering. Could he now find a way to manage the five points of resistance noted above, and move the Coalition towards the broader agenda the electorate plainly wanted? 
It soon became apparent that the portents were not good. While the poll boost that followed Turnbull's ascension lasted until the new year, by March 2016 polls were rating the parties at 50-50 and commentators were remarking on voter disappointment in a Prime Minister who 'hasn't appeared to do anything since coming to office' (Tingle 2016). Soon after, Newspoll (4 April) showed Labor ahead of the Coalition for the first time since Turnbull's rise. His willingness to talk, initially a boon after Abbott's three-word slogans, began to seem mere verbosity and lacked focus. He dithered over policy, pursuing leads that went nowhere (e.g. enthusiasm for a cities portfolio that withered when the responsible minister resigned following an incident unrelated to his portfolio), mooting grand plans (e.g. for addressing comprehensive tax reform) that then sank in the face of opposition, floating ill-considered thought bubbles apparently without consultation that disappeared within days (e.g. returning taxing powers to the States) and retreating from the very proposals (e.g. in relation to climate change) that had won him popular support. As Kroger was later to remark, in that period ... we were putting things on and off the table and the electorate formed the opinion, "well, if you fellas don't know what you're doing, that's a problem"' (Choahan 2016). Arguably, on such issues Turnbull had been reined in by the need to manage potential party dissent. (On climate change specifically it is said that a stipulation that he would not contravene Coalition policy had been included in a written agreement with the National Party.) But the abiding impression was of a risk-averse, indecisive leader. Only a significant election victory, it was argued, could restore his authority and keep his restive right wing 'a little more in its box' (Tingle 2016). Talk began to circulate about a doubledissolution election.

Then Turnbull initiated what some observers (e.g. Harper 2016) thought a masterstroke. He unveiled a Senate Reform bill intended to threaten the tenure of crossbenchers, and reintroduced blocked legislation (in particular, the Australian Building and Construction Commission (ABCC) bills) to the Senate. Thus, he issued a challenge that the crossbench either pass it or he would call a double-dissolution election.

While some saw this as Turnbull finally seizing the initiative to precipitate a 'crash-through' moment, a double-dissolution election, in halving the quota a candidate needed for Senate election, made it more, not less, likely that minority candidates would succeed. The Senate refused to be cowed and so a double-dissolution trigger was instituted; the Budget was presented and supply was assured; Turnbull duly visited the Governor-General 
and parliament was dissolved. The election campaign proper kicked off on 8 May 2016, when the election was formally announced. In effect, parties swung into campaign mode immediately after the 19 April press conference at which Turnbull had issued his challenge to the Senate over industrial relations legislation and outlined his plans for a double dissolution. It was to prove virtually the only instance of drama in the campaign. There was no further evidence of boldness on Turnbull's part.

While Shorten ramped up a process that had been in train for about a year, amplifying Labor's policy difference and demonstrating that he was prepared to take risks, Turnbull's presentation was unusual in that there was no single new policy announcement in the course of the campaign. The man who claimed to thrive on excitement and disruption was intent on presenting a small target. The focus was relentlessly on 'jobs and growth' (said to be assured by the budget measures, and especially by cuts to business taxes), the 'innovation agenda', border security and the need for stability in an uncertain world.

Following what is now the convention in electoral professional parties, the leaders on both sides were front and centre. Each crisscrossed the country for eight gruelling weeks, concentrating on marginal seats. In the senior Coalition team, Scott Morrison, Julie Bishop and Barnaby Joyce (for the Nationals) gained some attention, while others were occasionally highlighted for their gaffes. Peter Dutton, for instance, not only revealed the preferences of the party's Right, but also provoked outrage with a comment on refugees being illiterate and innumerate, taking Australian jobs and imposing burdens on health and social security (Bourke 2016). In the main, however, attention remained focused on Turnbull.

Yet now it was a controlled Turnbull, avoiding the very qualities that had made him attractive and never straying off message. It was, presumably intentionally, methodical and unexciting. Surrounded by party professionals, national campaign director Tony Nutt, cabinet secretary and former Howard chief of staff Arthur Sinodinos, principal strategist and pollster Mark Textor, and Vincent Woolcock, who had worked on Liberal campaigns right back to Malcolm Fraser, it might be said Turnbull was on a short leash. He was constantly presented with focus-group findings organised by Textor, and demanded that information be provided on every conceivable question that might come his way (Wright 2016). Everything needed was at his fingertips, but did he have direction? It was a reactive, defensive strategy rather than a forward-looking scheme. 
And far from facilitating 'intelligent conversation', Turnbull's perpetual resort to a signature slogan, 'jobs and growth', backfired to become a point of ridicule in letters to the Fairfax press, on social media and even a Facebook page, referring to a fictional character 'Jobson Grothe' (Sydney Morning Herald 2016).

There were three problems with the Turnbull campaign's strategy. First, the repeated invocation of 'jobs and growth' not only became an object of ridicule, but made sense only in relation to the assertion that business tax cuts would trigger both. Yet, the Coalition's own modelling indicated that the benefits would be relatively meagre. Any gains might well be further diminished by the capacity of multinationals to capitalise on those advantages offshore rather than investing in growth in Australia, and in any case they would appear a long way down the track. It was clearly based on a notion of trickle-down economics, and this at a time when the popular experience of the inequitable distribution of benefits from such reform was all too clear, and when the International Monetary Fund (IMF), the Organisation for Economic Co-operation and Development (OECD) and the World Bank had conceded that evidence was to the contrary.

Second, the innovation agenda-a policy suite providing incentives for start-ups, research and collaboration-while certainly providing for events where Turnbull could appear at his most knowledgeable and enthusiastic, encouraging his liveliest performances, also failed to enthuse voters. It concentrated on examples arguably only relevant to youthful, educated and savvy knowledge workers without pausing to explain what it would actually achieve for people who realised that their town would not be the next Silicon Valley, as the Liberal MP for Canning remarked (Koziol 2016b). In other words, Turnbull's initial pitch appeared insensitive to the real-life economic experience of much of the population.

Third, as these principal appeals lost traction, with Turnbull's net approval rating reaching its lowest point in mid-campaign, ${ }^{1}$ and Shorten progressively gaining ground on the policy front, Coalition leaders, particularly Turnbull and Morrison, resorted not to policy recalibration or 'intelligent conversation' about their initiatives, but to the danger represented by Labor's weakness on border protection, national security and economic management. Their overheated rhetoric about Labor's 'war'

1 Eleven per cent more voters questioned his performance rather than praised it (see Farr 2016). 
on business, on taxes, on assets, on house prices-all of them said to presage economic collapse-at first was called for what it was, a strained metaphor. But, at the last, the coincidence of the UK public's vote in favour of Brexit, provoking widespread international apprehension about a groundswell of electoral populism and the spectre of economic uncertainty, gave Turnbull ground for arguing that stability, security and sound management-which only the Coalition could promise-were a premium in such dangerously turbulent times.

Thus, Turnbull's campaign launch—on the last Saturday prior to the election - was framed by the invocation of uncertainty and volatility, in an attempt to give new life to the Coalition's interpretation of the economic agenda. ${ }^{2}$ National security was a prerequisite for economic security, which could only be guaranteed if voters resisted the urge to flirt with minor parties and the havoc they would cause to sensible plans to ensure stability-all the more necessary in a now-threatening environment. Disciplined immigration policy and border protection were more essential than ever in the unsettled climate. Brexit was explicitly referenced, and the other aspirations Turnbull flagged were all dependent on this central appeal for staying the course against the chaos and insecurity that would be unleashed if the wrong choice was made.

A Newspoll published two days later, on 27 June, showed the Coalition ahead for the first time in the campaign, 51 to 49 per cent on two-party preferred terms; the Turnbull campaign appeared at last to have found a message attuned to the moment. Turnbull's net approval had returned to roughly where it had been prior to the election. His performance lifted; he seemed to be keener, more focused and infused with confidence, but paradoxically appeared less frequently and travelled less at a time when Shorten's level of activity was as frenetic as ever. With the News Corporation Australia (News Corp) (Murdoch) press, which had in general remained staunchly pro-Turnbull, now opining that he was ahead and would remain there (e.g. Shanahan 2016a), he took his foot off the accelerator. In the closing days, it was almost as if the campaign had been won.

This proved a misreading of the electorate's mood. What the polls collectively had indicated all along — that there would be a near 50-50 split—came to pass. On the night of the election, it was not even clear if the

2 For a summary, see Australian Associated Press (AAP) (2016). 
Coalition would be returned, and Turnbull's bitter, bellicose post-midnight speech blamed everyone but himself, including, by implication, the voters said to have been taken in by Labor's 'grotesque "Mediscare"' campaign (for an analysis of the 'Mediscare' campaign, see Elliot and Manwaring, Chapter 24, this volume). It would take three days before he gave a more measured account and accepted responsibility for the campaign (Kenny 2016b). The election result would take still longer to clarify, but the final count ultimately saw the Coalition reduced to a single-seat majority in the House of Representatives. In the Senate, the government also lost ground and faced the prospect of having to wrangle support for its legislative program from an enlarged and potentially unmanageable crossbench that included conflicting blocs: nine Green Senators, four Pauline Hanson's One Nation Senators and three Nick Xenophon Team Senators.

The double-dissolution masterstroke had gone awry. Recriminations from the conservative Right were immediate and continuing: far from being 'back in their box', they were scarifying of a leadership that had failed to listen (Mcllroy 2016; Murphy 2016b). The victory Turnbull needed to establish his authority had eluded him. Many observers agreed that, as one put it, "he has not been the victim of outside forces, nor an ambush, nor terrible luck. He has inflicted the damage on himself ... This ... goes to Turnbull's real problem: he's not a very talented politician' (Carney 2016a). Even leading News Corp columnists, usually supportive of the Coalition (e.g. Albrechtsen 2016; Sheridan 2016), joined in the chorus questioning Turnbull's political astuteness.

\section{Shorten's campaign}

A familiar image of Shorten's campaign was of his daily early morning jogs through city streets, flanked by a contingent of younger, fitterlooking security officers and Labor volunteers. As ungainly as Shorten appeared on those runs, his fitness regime was one of several initiatives taken to strengthen his performance as he readied for the election contest. Another was personnel change at the top of his private office with the appointment of a new chief of staff (former Queensland Labor Party State Secretary Cameron Milner) and communications director (Ryan Liddell). Journalists noticed an improvement in his media appearances: 'his communications weren't inspired but they were sharper, the zingers [corny attempts at humour notoriously lampooned by satirist Shaun 
Micallef] binned, the woolly digressions trimmed' (Murphy 2016a). Shorten also credited the clearer focus to being more discriminating when it came to other sources of advice. It was reported that his most trusted counsellors were senior shadow ministers, Chris Bowen and Penny Wong, while confidants outside his parliamentary colleagues were former Victorian Labor premier Steve Bracks and ex-Australian Council of Trade Unions (ACTU) secretaries Bill Kelty and Greg Combet (Hyland 2016). The process of refining his message was further facilitated by Shorten embarking on a series of town hall-style meetings in marginal electorates. By the time the election campaign commenced, he had participated in around 25 of these events, each of them drawing hundreds of voters. The meetings were an opportunity 'to road test his rhetoric and his policies on the hot political issues of the day' (Anderson 2016).

Once the campaign was in swing, these preparations, and the longer-term policy development undertaken by Labor, reaped dividends. Shorten projected considerable surety and discipline on the hustings. He insistedand most observers accepted-that he was relishing the experience. Modern campaigns are invariably highly orchestrated affairs, but Shorten braved more direct encounters with the public than did a cloistered Prime Minister. While there is little evidence to suggest the leadership debates significantly impacted on the campaign, Shorten parlayed his greater ease in interacting with ordinary voters into a 'win' in the first of those encounters - a Sky News 'People's Forum' held in a western Sydney electorate. Shorten had proved more adept at responding to the 'hip pocket' concerns of audience members (Crowe 2016; Whinnett 2016). The sole free-to-air debate of the campaign was assessed to be a lacklustre affair and greeted with apathy by voters; however, with Shorten once more regarded as earning the upper hand (Taylor 2016; Bean, Chapter 10, this volume), it was perhaps telling that Turnbull declined another 'People's Forum'. He opted instead for an alternative 'online' debate, only to be again judged to have been outpointed by a punchier Shorten (Gartrell 2016; Owens 2016).

Possibly, the opposition leader benefited in these head-to-head match-ups against the Prime Minister because audiences had low expectations of him. However, a seasoned political correspondent surmised that the superior sensibilities displayed by Shorten on the campaign trail, compared to the Prime Minister, were also a product of contrasting backgrounds. Turnbull had been 'a top table guy ... He made his name impressing wealthy and powerful men: judges, bankers, CEOs'. Shorten, on the other hand: 
an organiser with the AWU, a blue collar union covering people who work with their hands across a wide range of industries ... learned how to win them over ... learned about the things that motivate them and concerned them in their lives (Carney 2016b).

Inevitably, Labor's was a leader-centric campaign. Yet, whether by necessity, given Shorten's distinct lack of celebrity power, or deliberately congruent with his positioning as a leader in touch with everyday voters, this was personalisation in monotone. Labor's travelling campaign road show-a coach popularly known as the 'Bill Bus', which was plastered with a giant headshot of Shorten-evinced the no-frills marketing of its leader. There was some effort to brighten his stolid image with his wife, Chloe, accompanying him on the hustings, but even those appearances mostly elicited a kind of self-deprecating 'aw shucks' routine from the Opposition Leader. Meanwhile, Shorten took the opportunity in interviews to disavow any ambition for individual predominance and restate his preference for collaborative leadership: 'I don't have to be the smartest person in the room; what I have to be good at is getting all the smart ideas in the room organised' (quoted in Hooper 2016); and, 'I'm a listener. My view of leadership is to be the coach ... My job is to coach a team to get the best out of people' (Ferguson, Stevens and Worthington 2016). Labor's campaign did give considerable prominence to the shadow ministers who made up the parliamentary party's leadership group, including Deputy Leader Tanya Plibersek, Bowen and Wong. It was a long way from the popstar 'presidential' campaigns of Rudd.

The contrast was also evident in policy terms. 'Shorten's 2016 Labor Party is a different beast to the Kevin Rudd party ... with Labor now more attuned to public sector Keynesianism, traditional unionbusiness rivalry and a highly redistributive tax policy', observed Paul Kelly (2016b). It was a theme that News Corp's stable of columnists persistently returned to throughout the campaign, painting Shorten as a throwback to antediluvian Labor populism (e.g. Kelly 2016c; Bramston 2016c). The media was collectively aghast when Labor announced they were planning to run higher deficits for the duration of next parliament. In a Four Corners special on the leaders a week out from polling day, Shorten was quizzed: 'Is that the moment you lost the election' (Ferguson, Stevens and Worthington 2016). In fact, Labor's focus on investment in core social policy areas had registered in the electorate. In early 2016, polling had shown that voters rated Turnbull in front of Shorten as the best to handle every major policy field. As the campaign headed towards 
its midway point, however, Shorten had jumped ahead of Turnbull in the areas of health, education and climate change, while the Prime Minister remained by far the preferred choice for managing the economy, national security and asylum seekers (Hudson 2016). It was clear evidence of a campaign in which each leader had aligned with their respective party's traditional strengths. For Labor, there was encouragement that health rated as the most important issue by voters. It was a trend that helped explain, as polling day neared, Shorten's increasingly shrill warnings about the Coalition being a threat to Medicare.

Polling also revealed that Shorten continued to edge upwards in voter estimates. Though still trailing behind Turnbull as preferred prime minister, by the final stages of the campaign the deficit had closed by around two thirds from the massive gulf of late 2015 (Shanahan 2016b). By historical measures, however, both leaders were unpopular-a point we return to below. Despite Shorten's improving ratings, and what little separated the Coalition and Labor on two-party preferred numbers, by the final fortnight of the campaign the consensus of the political media was that Shorten's momentum was stalling and that hopes for a Labor victory had largely vanished. 'Malcolm Turnbull is coming home with the wind in his sails, Shorten is running out of puff (Shanahan 2016a) typified the press gallery punditry. Confident that Labor was heading for defeat, there was a corresponding outbreak of journalistic speculation about Shorten's post-election fate since under Caucus rules the leadership would be automatically thrown open upon a loss. Unnamed Labor sources were quoted as saying that a gain of 10 seats was the benchmark for Shorten to retain factional support crucial to his leadership survival (Massola 2016; Clennell 2016).

Ironically, by all but writing off Labor's chances, the media unwittingly performed a favour for Shorten. When it became apparent on election night that Labor had exceeded their pessimistic forecasts, though not necessarily having done better than the polls had been signalling, his leadership assumed a triumphal aura. With the result still in doubt and the Prime Minister nowhere in sight, Shorten emerged to declare exultantly, 'there is one thing for sure-the Labor Party is back' (quoted in Harris 2016). In the afterglow, despite the chances of his cobbling together a minority government slipping away, and the reality that Labor's primary vote had been disappointing, Shorten's leadership was impregnable. Reports that Albanese might challenge him were swiftly snuffed out. In accordance with Caucus rules, nominations for the leadership were formally called 
for, but with Shorten the only nominee, he was re-elected unopposed. When reform of Labor's leadership selection system had been announced in 2013, two rationales had been provided: stability and empowerment of party members. For Shorten, the first objective had been fulfilled, but by forgoing a ballot the party had set aside the second with little compunction and an absence of protest by the rank and file.

\section{The significance of the 2016 leadership contest}

The 2016 federal election had a paradoxical legacy for the major party leaders. The winner, Turnbull, emerged a loser. His gamble on a doubledissolution election misfired. With his government's parliamentary position seriously weakened, he returned to office with his authority diminished rather than enhanced, and with his internal Liberal Party critics emboldened. On the other hand, despite Labor being defeated at the ballot box, Shorten had strengthened his hold over his party to the extent that he was re-elected to the leadership unopposed. Moreover, as a result of Labor's reformed leadership selection process, Shorten enjoys a distinct advantage in holding rivals at bay during a second term of opposition. After the election, Turnbull's leadership was under pressure rather than Shorten's.

Neither Turnbull nor Shorten were popular (Bean, Chapter 10, this volume), which continued a trend of the 2010 and 2013 federal elections of voters being seriously underwhelmed by both major party leaders. By the time of the election, Turnbull had haemorrhaged most of the public goodwill he had generated upon coming to office. At the same time, there is evidence (Bean, Chapter 10, this volume; van Onselen 2016) that had Abbott stayed prime minister, the Coalition would have been doomed at the election. With the caveat that it is impossible to test hypothetical alternative scenarios conclusively, Turnbull's leadership can be construed as having 'saved' the government. According to published opinion polls, Shorten incrementally improved his standing with the electorate during 2016. Yet this was from a low base and the approval he won from the public seemed to be grudging. Indeed, the best that can probably be said of the electoral effect of Shorten is that, while still a drag on Labor's vote (Bean, Chapter 10, this volume), he proved not to be quite the millstone for his party that had been feared going into the election year. The contest 
between the two men was a relatively benign affair lacking the intensity of the abrasive Abbott in the preceding elections. Shorten's profession to liking Turnbull (Gordon 2016a) illustrated the comparative civility. Correspondingly, the electorate, while not particularly favourable to either leader, did not much dislike them either. In short, this was a tepid contest in which the leaders failed to inspire strong feelings either way (Maley 2016). ${ }^{3}$

During the campaign neither leader strayed far from the established scripts of their respective parties. Turnbull did not live up to his reputation as a straight talker or philosophical free spirit within his party, straining credibility and undercutting his appeal in the electorate. For Shorten, close identification with his party mattered less since the electorate is unlikely to have ever regarded him as bigger than his party. He performed creditably as a tribal healer, but the failure to improve significantly on Labor's primary vote also suggested the limited utility of hugging a dwindling and increasingly unrepresentative party base. A question about Shorten going forward is whether he has the capacity to make the transition 'to a more creative and expansive project' on behalf of the Labor Party (Strangio 2016).

The 2016 election contest was inseparable from the leadership churn that preceded the advent of both Turnbull and Shorten, and demonstrated four things to which we should be alert in the campaign. First, leaders matter. For example, the surge in personal popularity enjoyed by Rudd on attaining party leadership and then the prime ministership was matched by a surge in the polls and the Labor vote. An equivalent pattern of poll support was enjoyed by Turnbull, and by his party, when he replaced Abbott in 2015. It is commonly argued that this is a consequence of the personalisation and mediatisation of the role in a leader-centric age (Brants and Voltmer 2011; Karvonen 2010; Wilson 2014). And it is why leaders who pass the popularity test (like Rudd and Turnbull) are granted so much authority in contemporary politics. However, it is important to remember that the voter connection to a leader is not simply a response to individual qualities or strength. Rather, leaders have come to 'stand in' for the party (McAllister 2011: 240-65). As class and

3 The ABC's Vote Compass survey indicated that, rated on questions of competence and trustworthiness, Turnbull maintained a slim advantage over Shorten. However, the ratings of both leaders largely plateaued during the campaign and seemed to confirm that the electorate had lukewarm feelings towards both (see Blumer 2016). 
ideology have declined as voter ties, leader communication has come to represent what a party stands for. Hence, the second factor: the leader must now perform as communicator-in-chief, an element now commonly identified as the crucial lack in Gillard's leadership performance. Turnbull also showed himself deficient in this respect, or at least did not meet the high expectations attached to him. Conversely, though an unpretentious communicator, Shorten performed more persuasively than anticipated.

Third, as was noted long ago (Kemp 1973), there must be a convincing combination of authority and philosophy. This latter element is now even more important as voters take a shortcut in leader assessment in determining consistency of purpose and what a party is likely to do to their benefit or detriment. When leaders base their pitch on some key element and then walk away (as Rudd did in elevating the response to climate change as the great moral issue of our time, then abandoning the cause, or as Abbott did in swiftly breaking promises made in his election campaign), there will be a savage voter response with ramifications not only for that leader, but for their party, as both Rudd and Abbott found to their cost. In the end, popularity would not shore up Turnbull either; taking things on and off the table, defaulting to trickle-down economics and resorting to sloganeering eroded his claim to authenticity. In contrast, Shorten's efforts to link new policy to Labor values, though derided as archaic by News Corp journalists, found their mark and enabled him to reel in the always more popular Turnbull.

Fourth, the leader's task in conveying a message that reconciles broad public opinion and the demands of the party base is now more difficult than ever as the major parties are fragmenting and proliferating media channels have become less reliable as a means of aggregating opinion. There has long been concern in Labor Party circles about the difficulty of harnessing the interests of postmaterialist progressives with those of the residual working-class battlers. Less attention, however, has been given to the divisions in the Coalition between moderate, cosmopolitan, progressive individualists and so-called conservatives — a rather misleading designation, given that it has come to represent a somewhat contradictory amalgam of social illiberalism and market fundamentalism that has little relation to the tradition of respect for institutions, cautious, incremental reform and community obligation once characteristic of the Liberal Party (Menzies 1943). 
There is a heightened risk, in these circumstances, for a leader who is handcuffed to the party base, or even a faction within the party-whether by sympathy, necessity or a combination of both - to find themselves out of step with what the electorate wishes. With respect to the Coalition parties, for instance, such divergence between the party world view and public sentiment has been clearly demonstrated in relation to climate change (Fielding et al. 2012; Leviston, Greenhill and Walker 2015: 45-48; Lowy Institute 2015: 3, 13-14; Slezak 2016), economic policy (Lowy Institute 2015: 7-8), and marriage equality (Hudson 2015b; Sparrow 2016). Abbott's unabashed alignment with the socially illiberal, market fundamentalist opinion within the Coalition in government is arguably what caused his downfall. Turnbull's initial appeal was that he appeared to speak for a broader, more progressive liberalism, and one attuned to issues that resonated with a larger constituency than that with which Abbott and his supporters identified. Turnbull's difficulty in sustaining such a message while containing party dissenters was a significant feature of the 2016 campaign. He did everything he could to avoid provoking the conservative wing during his campaign, but the compromises were never enough (Murphy 2016b). It will be a continuing challenge.

The interplay of all four factors that had so much effect in precipitating previous leadership churn surfaced in both major party leaders' 2016 election campaign performances, with decisive effects on the election outcome. The capacity to manage them will continue to shape the politics of leadership, most particularly for the prime minister who must now battle for the authority that the election failed to yield.

\section{References}

Abbott, Tony. 2015. 'Tony Abbott's speech in full: "Our country is so much better than this"'. Guardian, 14 September. Available at: www. theguardian.com/australia-news/2015/sep/14/tony-abbotts-speechin-full-our-country-is-so-much-better-than-this

Albrechtsen, Janet. 2016. 'Malcolm Turnbull's pinball politics and power without glory'. Weekend Australian, 10 August. Available at: www. theaustralian.com.au/opinion/columnists/janet-albrechtsen/malcolmturnbulls-pinball-politics-and-power-without-glory/news-story $/ 6897 \mathrm{f}$ 6ed6782e0df0f5d75d681f13ba1 
Anderson, Fleur. 2016. 'The poll backroom teams revealed: Election 2016'. Financial Review, 9 May, p. 6.

Australian Associated Press (AAP). 2016. 'What Turnbull covered at campaign launch'. SBS, 26 June. Available at: www.sbs.com.au/ news/article/2016/06/26/what-turnbull-covered-campaign-launch

Blumer, Clare. 2016. 'Vote Compass: Malcolm Turnbull maintains lead on question of who voters trust'. ABC News, 30 June. Available at: www.abc.net.au/news/2016-06-29/election-2016-vote-compassturnbull-shorten-trust/7549918

Bourke, Latika. 2016. 'Peter Dutton says "illiterate and innumerate" refugees would take Australian jobs'. Sydney Morning Herald, 18 May. Available at: www.smh.com.au/federal-politics/federal-election-2016/ peter-dutton-says-illiterate-and-innumerate-refugees-would-takeaustralian-jobs-20160517-goxhj1.html

Bramston, Troy. 2016a. 'Deadweight Shorten sinking fast in Turnbull tide'. Australian, 1 February. Available at: www.theaustralian.com.au/ opinion/columnists/troy-bramston/dead-weight-shorten-sinking-fastin-turnbull-tide/news-story/f2ab8b0aa1a445cdbaef0f51b23e3a7f

__ 2016b. 'Turnbull effect drove "Kill Bill" plotters'. Australian, 5 July. Available at: www.theaustralian.com.au/opinion/columnists/troybramston/federal-election-2016-result-spares-shorten-leadershipchallenge/news-story/f406c3b42dbe653dc4685f5d9021bfb3

__. 2016c. 'Labor cannot win unless it grabs middle ground'. Weekend Australian, 25 June, p. 18.

Brants, Kees and Katrin Voltmer. 2011. Political Communication in Postmodern Democracy: Challenging the Primacy of Politics. London: Palgrave Macmillan. doi.org/10.1057/9780230294783

Brett, Judith. 2013. 'Prime Ministers and their parties in Australia'. In Paul Strangio, Paul 't Hart and James Walter (eds), Understanding Prime-Ministerial Performance: Comparative Perspectives. Oxford: Oxford University Press, pp. 172-92.

Carney, Shaun. 2016a. 'Turnbull has only himself to blame'. Sydney Morning Herald, 4 July. Available at: www.smh.com.au/comment/ turnbull-has-only-himself-to-blame-20160704-gpxwic.html 
— 2016b. 'Federal election 2016: Bill Shorten shows the value of persistence'. Herald Sun, 4 July. Available at: www.heraldsun.com.au/ news/opinion/federal-election-2016-bill-shorten-shows-the-value-ofpersistence/news-story/06ea7fe875da8161548ef02e90be38f0

Choahan, Neelima. 2016. 'Malcolm Turnbull's economic policies to blame for election debacle: Michael Kroger'. Sydney Morning Herald, 9 July. Available at: www.smh.com.au/federal-politics/federal-election-2016/ turnbulls-economic-policies-to-blame-for-election-debacle-kroger20160709-gq233a.html

Clennell, Andrew. 2016. 'Knives are out'. Daily Telegraph, 30 June, p. 7.

Crabb, Annabel. 2016. Stop at Nothing: The Life and Adventures of Malcolm Turnbull. Revised edition. Melbourne: Black Inc.

Crowe, David. 2016. 'First blood to Shorten, say audience voters'. Weekend Australian, 14 May, p. 1.

Errington, Wayne and Peter van Onselen. 2015. Battleground: Why the Liberal Party Shirtfronted Tony Abbott. Melbourne: Melbourne University Press.

Farr, Malcolm. 2016. 'Approval decline of Turnbull Mark: 1 and Turnbull Mark: 2 in synch'. news.com.au, 3 June. Available at: www.news.com. $\mathrm{au} /$ national/federal-election/approval-decline-of-turnbull-mark-1and-turnbull-mark-2-in-synch/news-story/47a7cadbe08c95463d572 $0419 \mathrm{~d} 296 \mathrm{a} 14$

Ferguson, Sarah, Justin Stevens and Elise Worthington. 2016. 'The Leaders'. Four Corners, $A B C$, 27 June. Available at: www.abc.net. au/4corners/stories/2016/06/27/4487476.htm

Fielding, Kelly, Brian Head, Warren Laffan, Mark Western, Mark and Ove Hoegh-Guldberg. 2012. 'Australian politicians' beliefs about climate change: Political partisanship and political ideology'. Environmental Politics 21(5): 712-33. doi.org/10.1080/09644016.2012.698887

Gartrell, Adam. 2016. 'Shorten delivers best line of the night'. Canberra Times, 18 June, p. 5.

Gordon, Michael. 2016a. 'Home brand election - all elections are crucial, but this will be a contest like no other'. Age, 7 May, p. 34. 
__. 2016b. 'Can he do it?' Age, 28 May, p. 26.

Hall, Lauren and Ngaire Donaghue. 2012. "Nice girls don't carry knives": Constructions of ambition in media coverage of Australia's first female prime minister'. British Journal of Social Psychology 20(3): 631-47. doi.org/10.1111/j.2044-8309.2012.02114.x

Harper, Cathy. 2016. 'The PM has painted a very clear picture'. Election Watch, 21 March. Available at: electionwatch.unimelb.edu.au/ australia-2016/articles/the-pm-has-painted-a-very-clear-picture

Harris, Rob. 2016. 'It's too close to call'. Sunday Telegraph, 3 July, p. 5.

Hooper, Chloe. 2016. 'Could he actually win? On the road with Bill Shorten'. Monthly, June. Available at: www.themonthly.com.au/ issue/2016/june/1464703200/chloe-hooper/could-he-actually-win

Hudson, Phillip. 2015a. 'Shorten now Mr 15pc with voters'. Australian, 24 November, p. 4.

_- 2015b. 'More Australians back change to allow same-sex marriage'. Australian, 17 June. Available at: www.theaustralian.com.au/nationalaffairs/newspoll/more-australians-back-change-to-allow-samesexmarriage/news-story/1f645f84cb458c9648d9e80f0d564592

—_. 2016. 'Voters put their faith in Shorten to handle health'. Australian, 24 May, p. 6.

Hyland, Anne. 2016. 'Team Shorten: The people giving Labor a strong start'. Australian Financial Review, 14 May, p. 14.

Jackman, Christine. 2008. Inside Kevin 07: The People. The Plan. The Prize. Melbourne: Melbourne University Press.

Karvonen, Lauri. 2010. The Personalization of Politics: A Study of Parliamentary Democracies. Colchester: ECPR Press.

Kelly, Paul. 2016a. 'Economic vision vs "man of the people"'. Australian, 9 May, p. 2.

_ _ 2016b. 'Shorten reveals Labor's big policy shift over the decade'. Weekend Australian, 28 May, p. 19.

__. 2016c. 'Showdown time for Shorten and his big gamble'. Australian, 29 June, p. 14. 
Kemp, David. 1973. 'A leader and a philosophy'. In Henry Mayer (ed.), Labor to Power: Australia's 1972 Election, pp. 48-59. Sydney: Angus and Robertson. doi.org/10.1080/00323267308401321

Kenny, Mark. 2016a. 'Rivals neck and neck as PM pulls trigger'. Age, 9 May, p. 1.

—. 2016b. 'It was all my fault: Turnbull's mea culpa'. Age, 6 July, p. 1.

Koziol, Michael. 2016a. 'Continuity and change: Malcolm Turnbull's nod to the foregone but fixed on the future'. Sydney Morning Herald, 22 March. Available at: www.smh.com.au/federal-politics/politicalopinion/continuity-and-change-malcolm-turnbulls-nod-to-theforegone-but-fixed-on-the-future-20160321-gnnxez.html

_ 2016b. 'How Malcolm Turnbull's innovation agenda failed to take flight'. Sydney Morning Herald, 18 July. Available at: www.smh.com.au/ federal-politics/political-news/how-malcolm-turnbulls-innovationagenda-failed-to-take-flight-20160714-gq5dwu.html

Leviston, Zoe, Murni Greenhill and Iain Walker. 2015. Australian Attitudes to Climate Change: 2010-2014. Canberra: CSIRO.

Lowy Institute. 2015. The Lowy Institute Poll 2015. Sydney: Lowy Institute.

Maley, Jacqueline. 2016. 'Voters display disinterest in both leaders'. Age, 14 May, p. 4.

Manne, Robert. 2012. 'One morning with Malcolm'. Monthly, April. Available at: www.themonthly.com.au/issue/2012/april/1337744204/ robert-manne/one-morning-malcolm

Manning, Paddy. 2015. Born to Rule: The Unauthorised Biography of Malcolm Turnbull. Melbourne: Melbourne University Press.

Marr, David. 2015. 'Faction man: Bill Shorten's path to power'. Quarterly Essay 59. Available at: www.quarterlyessay.com.au/essay/2015/09/ faction-man/extract

Massola, James. 2016. 'Take 10 seats or it's bye-bye Bill, say hardheads'. Sydney Morning Herald, 28 June, p. 4. 
McAllister, Ian. 2011. The Australian Voter: 50 Years of Change. Sydney: UNSW Press.

McIlroy, Tom. 2016. 'Election 2016: Liberal senator Corey Bernardi says Malcolm Turnbull's future is up for debate'. Sydney Morning Herald, 4 July. Available at: www.smh.com.au/federal-politics/federalelection-2016/election-2016-liberal-senator-cory-bernardi-saysmalcolm-turnbulls-future-is-up-for-debate-20160704-gpxuqe.html

Medhora, Shalailah. 2016. 'Polls spell trouble for Coalition as Turnbull's approval rating plummets'. Guardian Australia, 17 April. Available at: www.theguardian.com/australia-news/2016/apr/18/polls-spell-troublefor-coalition-as-turnbulls-approval-rating-plummets

Menzies, Robert. 1943. The Forgotten People: And other Studies in Democracy. Sydney: Angus and Robertson.

Murphy, Katharine. 2016a. 'Lucky man: Has Bill Shorten got what it takes?' Guardian Australia, 9 May. Available at: www.theguardian. com/australia-news/2016/may/09/bill-shorten-election-2016-laboralp-essay

__ 2016b. 'Turnbull tried and failed to appease the right - now he has nowhere to turn'. Guardian Australia, 5 July. Available at: www. theguardian.com/australia-news/2016/jul/05/turnbull-overseeingliberals-implosion-and-neither-side-wants-to-sue-for-peace

Owens, Jared. 2016. 'PM pushes Facebook chat over live debate'. Australian, 7 June, p. 7.

Shanahan, Dennis. 2016a. 'Malcolm Turnbull is sailing home with the wind in his hair'. Australian, 1 July, p. 6.

__. 2016b. 'Voters are struggling to decide which leader they distrust more'. Australian, 21 June, p. 6.

Sheridan, Greg. 2016. 'Turnbull yet to master transactional politics'. Australian, 5 July. Available at: www.theaustralian.com.au/news/ inquirer/federal-election-2016-turnbull-yet-to-master-transactionalpolitics/news-story/f5a831754fd043a26345638973170365

Shorten, Bill. 2016. For the Common Good: Reflections on Australia's Future. Melbourne: Melbourne University Press. 
Slezak, Michael. 2016. 'Climate change a vote-changer at federal election, says poll'. Guardian Australia, 16 March. Available at: www. theguardian.com/environment $/ 2016 / \mathrm{mar} / 17 /$ climate-change-a-votechanger-at-federal-election-says-poll

Sparrow, Jeff. 2016. 'Don't fear the people: A plebiscite will confirm the Australian public's support for marriage equality and marginalise bigots'. Monthly, 26 July. Available at: www.themonthly.com.au/blog/ jeff-sparrow/2016/26/2016/1469500968/don-t-fear-people

Strangio, Paul. 2016. 'Shorten the consensus leader unites a fractured Labor, but it may not be quite enough'. The Conversation, 30 June. Available at: theconversation.com/shorten-the-consensus-leader-unitesa-fractured-labor-but-it-may-not-quite-be-enough-61741

Strangio, Paul and James Walter. 2015. 'The leadership contest: An end to the "messiah complex"?' In Carol Johnson and John Wanna with HsuAnn Lee (eds), Abbott's Gambit: The 2013 Election. Canberra: ANU Press, pp. 49-63. doi.org/10.22459/AG.01.2015.03

Sydney Morning Herald. 2016. 'Vote one for Jobson Grothe'. Sydney Morning Herald, 12 May. (Original: 'Election 2016: Coalition "jobs and growth" mantra backfires'). Available at: www.smh.com.au/ comment/smh-letters/vote-one-for-jobson-grothe-20160511-gos9by. html

Taylor, Lenore. 2016. 'No winners on election debate night when answers were scripted and ideas untested'. Guardian Australia, 29 May. Available at: www.theguardian.com/australia-news/2016/may/29/nowinners-election-debate-night-answers-scripted-ideas-untested

Tingle, Laura. 2016. 'Malcolm Turnbull's greatest hits: A whole lot of faffing is costing votes'. Australian Financial Review, 10 March. Available at: www.afr.com/opinion/malcolm-turnbulls-greatest-hits-awhole-lot-of-faffing-is-costing-votes-20160310-gnfnqa

Turnbull, Malcolm. 2015. 'Vote on the Liberal Party leadership', 15 September. Transcript. (Original: 'Transcript of the Hon Malcolm Turnbull and the Hon Julie Bishop MP Press Conference, Parliament House'). Available at: www.malcolmturnbull.com.au/media/transcriptvote-on-the-liberal-party-leadership 
van Onselen, Peter. 2015. 'Five-point détente would win Malcolm Turnbull right to rule'. Weekend Australian, 28 February, p. 22.

—_. 2016. 'Coalition's pyrrhic victory'. Australian, 4 July, p. 11.

Whinnett, Ellen. 2016. 'Shorten given an easy ride'. Herald Sun, 14 May, p. 6.

Wilson, Jason. 2014. 'Kevin Rudd, celebrity and audience democracy in Australia'. Journalism 15(2): 202-17. doi.org/10.1177/1464884 913488724

Wright, Tony. 2016. 'Smooth sailing'. Sunday Age, 3 July, p. 8. 
This text is taken from Double Disillusion: The 2016 Australian Federal Election, edited by Anika Gauja, Peter Chen, Jennifer Curtin and Juliet Pietsch, published 2018 by ANU Press, The Australian

National University, Canberra, Australia.

doi.org/10.22459/DD.04.2018.04 